\title{
New manufacturing methodology for boron-based rods for remedial treatments of wood: solubilities and some physical and thermal properties of the rods
}

\author{
Seçil Aydın $^{1} \cdot$ Evren Terzi $^{2}$ · S. Nami Kartal ${ }^{2}$ Sabriye Pişkin ${ }^{1} \cdot$ Serpil Kılıç Depren $^{3} \cdot$ Aysel Kantürk Figen $^{1}$ (]
}

Received: 12 May 2020 / Accepted: 28 September 2020 / Published online: 8 October 2020

(c) Springer Nature Switzerland AG 2020

\begin{abstract}
Boron-based rods are ideal for remedial treatments in wood attacked by decay fungi, insects and termites as well as for preventive treatments of high-risk areas in structural timbers and logs internally. This study evaluated the solubility, some physical and thermal properties of the boron-based rods manufactured from either raw ulexite mineral, raw colemanite mineral, di-sodium octaborate tetrahydrate (DOT), and their combination of silica-based plasticizer. This is the first attempt to produce ulexite and colemanite-based boron rods with/without additional compound by an extruder. To take the advantages of boron minerals, rods were produced with paste mixtures of boron compounds and plasticizer by a single-screw extrusion method. Solubility and thermal resistance tests as well as micro-hardness tests were performed to determine the quality and strength of the rods for discussing the on-site applications. The paste content was an important factor affecting the transport processes during single screw extrusion with special emphasis on the rod formation. No macro-structural changes were observed when the boron rods were exposed to heat at 30, 50, 70, 100 , and $200^{\circ} \mathrm{C}$. According to the Kruskal-Wallis test, no significant difference was observed in micro-hardness values of thermally treated boron-based rods; however, at high temperatures up to $50^{\circ} \mathrm{C}$, there was a decrease in hardness of DOT rods. The rods manufactured by extrusion methods showed similar water solubility when compared to raw ulexite and colemanite minerals.
\end{abstract}

Keywords Rods · Boron · Ulexite $\cdot$ Colemanite $\cdot$ Remedial treatments $\cdot$ Wood

\section{Introduction}

There is a continually growing interest in the use of remedial treatments to increase the service life of wood and wooden structures against biodegradation by fungi, insects, and termites. The service life of wooden members in buildings can be considerably increased by remedial or in-place treatments by using various technologies and preservative chemicals. Such wood protecting chemicals for remedial treatments are generally categorized as shown
[1, 2]: (1) Thixotropic pastes and preservative greases, (2) oil borne and waterborne solutions, and emulsions, (3) preservative rods and pads, and (4) liquid and solid fumigants.

The main aim of remedial treatments is to distribute preservative compounds into the zones of a wood member in structures exposed to moisture/wetting or not previously protected by wood protecting chemicals [3]. Various modes of movement and efficacy are available for each chemical stated above. Solubility and distribution of

Aysel Kantürk Figen, akanturk@yildiz.edu.tr| ${ }^{1}$ Department of Chemical Engineering, Faculty of Chemistry-Metallurgical, Yıldız Technical University, 34210 Davutpasa Esenler, Istanbul, Turkey. ${ }^{2}$ Department of Forest Biology and Wood Protection Technology Faculty of Forestry, Istanbul University-Cerrahpaşa, 34473 Bahcekoy, Istanbul, Turkey. ${ }^{3}$ Department of Statistics, Faculty of Arts and Science, 34210 Davutpasa Esenler, Istanbul, Turkey. 
preservative chemicals in wood for remedial treatments and duration of efficacy might be also different [2].

Remedial treatments are generally applied to the wood having a specific amount of moisture in its structure (higher than $28 \%$ ) to get better diffusion of protective chemicals in the wood. Termites are also able to infest moist wood depending on the species (subterranean termites vs. dry wood termites). Thus, both conventional and remedial treatments bring benefits to the wood in terms of protection [3].

Among preservatives for remedial treatments, boronbased rods are one of the most effective methods since boron compounds are easily absorbed and penetrate by diffusion mechanism into the wood structure. Boron is an extremely effective natural wood preservative compound with broad activity against wood degrading organisms. Boron wood preservatives are also considered as costeffective, colorless, and non-volatile compounds. Also, no evaporation, degradation, odor, or corrosion occurs inservice conditions $[2,4,5]$.

Boron is still one of the main and side components of wood preservatives on the market in the EU. Not only a wood preservative but also as components of a wide range of industrial applications from glass to agriculture, EU countries use boron element [6]. Disodium octaborate tetrahydrate (DOT) is specially formulated for use as a water-based wood preservative and is registered by EPA as well as government agencies throughout Asia, North America and Europe. Typical applications include furnishings and interior construction, such as framing, sheathing, sill plates, furring strips, trusses, and joists [7].

A common methodology for manufacturing boron rods is fusion technology in which the rod is produced by heating disodium octaborate to a molten state so that it can be poured into molds. The borate hardens into an easily handled, glass-like rod as it cools [8]. A US Patent $(5,612,046)$ states that Australian Patent No. 527,240 indicates the use of a fused monolithic body of boric oxide $[9,10]$. As the shaped monolithic bodies are formed by a melt extrusion process over $1000^{\circ} \mathrm{C}$ practical processing difficulties arise, and the use of these bodies has not gained wide acceptance due to their high cost and slow release of boron in wood with moisture content even higher than $25 \%$. Another US patent $(4,661,157)$ states the employment of water-binding capability boron compounds to form rods by hydration [11]. The hydration of boron compounds by the suggested methodology occurs fast and final rod products are relatively low in density and strength. The above-mentioned patents follow the mixing of the boron compounds with several carrier compounds to increase strength; however, this affects reducing the relative ratios of active ingredients in the final rods and effectiveness as well [9]. The US Patent 5,612,046 suggests a different methodology to produce stronger and denser rods by the hydration of boron and fluorine compounds. The method is applied to form a dry mixture by adding water to form a paste, shaping the paste, and allowing the paste to set to form the shaped rod.

This study aimed to manufacture boron rods from raw boron minerals namely ulexite and colemanite to decrease production costs over commercially available boron rods from generally DOT. Although boron minerals and compounds have already been used for remedial treatments of wood, there is no previously published paper about singlescrew extrusion method for the fabrication of boron-based rods. The objective of the recent study was to determine whether boron rods from ulexite and colemanite minerals could be produced with/without additional compounds and by an extruder without fusion application which is a conventional method for commercial boron rods. In addition to this, for possible on-site applications, some physical properties were tested and reported.

\section{Materials and methods}

\subsection{Preparation of paste mixtures}

Ulexite $\left(\mathrm{NaCaB}_{5} \mathrm{O}_{9} \cdot 8 \mathrm{H}_{2} \mathrm{O}, 45 \mu \mathrm{m}\right)$ mineral, colemanite $\left(\mathrm{Ca}_{2} \mathrm{~B}_{6} \mathrm{O}_{11} \cdot 5 \mathrm{H}_{2} \mathrm{O}, 45 \mu \mathrm{m}\right)$ mineral, and di-sodium octaborate tetrahydrate (DOT) $\left(\mathrm{Na}_{2} \mathrm{~B}_{8} \mathrm{O}_{13} \cdot 4 \mathrm{H}_{2} \mathrm{O}\right)$ were selected to manufacture boron-based rods and supplied from ETI MADEN (Ankara, Turkey). Their chemical structures are listed in Table 1 [12]. The minerals and DOT were used as it is, and no further purification process was applied.

\subsection{Manufacturing of boron-based rods}

The boron rods were manufactured with either ulexite or colemanite minerals or DOT by a single-screw extrusion method. In some formulations of pastes, a silicatebased plasticizer was used as a processing additive and the pastes consisting of plasticizer at $2 \mathrm{wt} \%$ were prepared for comparison. Table 2 summarizes the optimum compositions of the pastes to obtain better extraction processability for rod manufacture.

Extrusion was carried out by the following procedure. In each set of pastes, a total weight of $1 \mathrm{~kg}$ was fixed as a basis. Firstly, the required amounts of components were calculated and then ulexite/colemanite/DOT or their combination with plasticizer was mixed with water. Then, the mixture was stirred vigorously to ensure homogeneity. The extrusion was carried out by a using single-screw extruder (REMSAN, Istanbul, Turkey). The prepared paste mixtures were then introduced into the feed throat of the extruder with a single screw and conveyed into the screw by its 
Table 1 Chemical structure and particle size distribution of colemanite, ulexite and DOT

\begin{tabular}{llll}
\hline Component & Colemanite & Ulexite & DOT \\
\hline $\mathrm{B}_{2} \mathrm{O}_{3}(\%)$ & $40.00 \pm 0.50$ & $37.00 \pm 1.00$ & 67.00 \\
$\mathrm{CaO}(\%)$ & $27.00 \pm 1.00$ & $19.00 \mathrm{Max}$ & - \\
$\mathrm{SiO}_{2}(\%)$ & $4.00-6.50$ & $4.00 \mathrm{Max}$ & - \\
$\mathrm{SO}_{4}(\%)$ & $0.60 \mathrm{Max}$ & $0.25 \mathrm{Max}$ & - \\
$\mathrm{As}^{(p p m)}$ & $35 \mathrm{Max}$ & $40.00 \mathrm{Max}$ & $<0.010$ \\
$\mathrm{Fe}_{2} \mathrm{O}_{3}(\%)$ & $0.08 \mathrm{Max}$ & $0.04 \mathrm{Max}$ & - \\
$\mathrm{Al}_{2} \mathrm{O}_{3}(\%)$ & $0.40 \mathrm{Max}$ & $0.25 \mathrm{Max}$ & - \\
$\mathrm{MgO}(\%)$ & $3.00 \mathrm{Max}$ & $2.50 \mathrm{Max}$ & - \\
$\mathrm{SrO}^{(\%)}$ & $1.50 \mathrm{Max}$ & $1.00 \mathrm{Max}$ & - \\
$\mathrm{Na}{ }_{2} \mathrm{O}(\%)$ & $0.50 \mathrm{Max}$ & $3.50 \mathrm{Min}$ & 14.92 \\
$\mathrm{LOI}(\%)$ & $25.00 \mathrm{Max}$ & - & - \\
$\mathrm{Moisture} \mathrm{( \% )}$ & $1.00 \mathrm{Max}$ & $1.00 \mathrm{Max}$ & - \\
$\mathrm{Bulk}$ density (tone $\left./ \mathrm{m}^{3}\right)$ & $1.00 \mathrm{Max}$ & $1.00 \mathrm{Max}$ & - \\
$\mathrm{Particle} \mathrm{size}(\mu \mathrm{m})$ & & & \\
+150 & $0.25 \% \mathrm{Max}$ & $0.25 \% \mathrm{Max}$ & - \\
-45 & $75.00 \% \mathrm{Min}$ & $75.00 \% \mathrm{Min}$ & - \\
-90 & - & - & $50 \% \mathrm{Min}$ \\
\hline
\end{tabular}

Table 2 Contents of the pastes prepared for manufacturing boron rods $(\%, w / w)$

\begin{tabular}{llllll}
\hline $\begin{array}{l}\text { Rod/ } \\
\text { paste } \\
\text { type }\end{array}$ & Colemanite & Ulexite & $\begin{array}{l}\text { DOT } \\
\text { Silicate- } \\
\text { based } \\
\text { plasticizer }\end{array}$ & Distilled water \\
\hline R-1 & - & 80.6 & - & - & 19.4 \\
R-2 & - & 82.4 & - & 2 & 15.6 \\
R-3 & 84.7 & - & - & - & 15.3 \\
R-4 & 83.3 & - & - & 2 & 14.7 \\
R-5 & - & - & 71.4 & - & 28.6 \\
R-6 & - & - & 72.6 & 2 & 25.4 \\
\hline
\end{tabular}

turning motion. The barrel allowed to have in the form of rods approximate size $9 \mathrm{~mm}$ diameter. No heat was applied during the process. The pressure was generated to enable the paste to be conveyed into the shaping area. The produced continuous type rods were then cut by a knife to desired rod lengths. The cut rods were air-dried for $24 \mathrm{~h}$ before further tests.

\subsection{Thermal properties of raw boron minerals and DOT}

Thermal properties of raw ulexite and colemanite minerals and DOT were investigated by thermal analysis technique (Perkin Elmer Pyris Diamond TG/DTG). The boron minerals and DOT in powder form $(\sim 10 \mathrm{mg})$ were heated under $\mathrm{N}_{2}$ atmosphere $(100 \mathrm{ml} / \mathrm{min})$ in the $30-900{ }^{\circ} \mathrm{C}$ temperature range with a $10^{\circ} \mathrm{C} / \mathrm{min}$ of heating rate.

\subsection{Thermal resistant of manufactured boron rods}

Tests were applied to observe thermal resistant temperature in which the boron rods can maintain their rod structure when exposed to heat. The boron rods were heat-treated at different temperatures in two groups as low $\left(30^{\circ} \mathrm{C}, 50^{\circ} \mathrm{C}\right.$ and $\left.70^{\circ} \mathrm{C}\right)$ and high $\left(100^{\circ} \mathrm{C}, 200^{\circ} \mathrm{C}\right.$ and $400^{\circ} \mathrm{C}$ ) temperatures for $2.5 \mathrm{~h}$ in a laboratory-type furnace. After the process, changes in the rod forms were visually examined and pictures were taken.

\subsection{Micro-hardness of manufactured boron rods}

Vickers micro-hardness tests are widely performed to investigate the relation between mechanical properties and structure [13]. The Vickers test was applied to boron rods and heated boron rods by dipping the pyramidshaped diamond tip, which has a square and a top angle of $136^{\circ}$, into the material under $200 \mathrm{gr}$ loads and the formed trace size was measured. Micro-hardness $\left(H_{v}\right)$ was calculated according to Eq. 1. Three measurements were taken for each bar. If the values of the values are very different from each other, the number of measurements has been increased to 5 , and mean values are used as one observation with standard deviation.

$H_{\mathrm{v}}=0.102\left(F / d^{2}\right)$

where $F$ is the applied load, 1.102 is a geometrical constant of the diamond pyramid of the indenter, and $d$ is the media of two indentation diagonal lengths.

\subsection{Density of manufactured boron rods}

The density of boron rods was calculated based on Archimedes' Principle. After being weighed, (RADWAG, AS R2 PLUS, the accuracy of $\pm 0.01 \mathrm{mg}$.), the rods were submerged in distilled water then weighed out of distilled water at room temperature $(1.5 \mathrm{~ms} / \mathrm{cm})$. Density was calculated according to Eq. 2.

$\rho_{\mathrm{s}}=m_{\mathrm{o}} /\left(m_{\mathrm{o}}-m_{1}\right) \rho_{\mathrm{w}}$

where $\rho_{s}$ is the density of the rod, $m_{0}$ is the weight of the sample out of the rod, $m_{1}$ is the weight of the rod submerged in water, and $\rho_{\mathrm{w}}$ is the density of distilled water at a given temperature.

\subsection{Solubility}

The water solubility of boron-based rods was determined as a function of time. For comparison, raw boron minerals and DOT in powder form were also employed. The rods or powdered boron compounds in equal weights were 
soaked in ultra-pure water for $6 \mathrm{~h}, 1$ day, 2 days, and 4 days. After being reached the desired time, the solutions were filtrated, and boron content was determined by ICP-OES technique ICP-AES Multitype ICP Emission Spectrometer (Shimadzu ICPE-9000, Tokyo, Japan).

\subsection{Statistical methods}

The analysis of variance (ANOVA) is used to compare mean scores of more than two groups. Once the normality assumptions for ANOVA are not met, nonparametric alternatives are considered to compare the distributions across groups. One of the alternative tests of the ANOVA is the Kruskal-Wallis, which compares the distributions of more than two independent samples. The Kruskal-Wallis test has two basic assumptions: (1) the variables are random and independent and (2) the dependent variable is ordinal or metric [14].

The null $\left(H_{0}\right)$ and alternative hypotheses $\left(H_{1}\right)$ for the Kruskal-Wallis test are stated as follows:
$H_{0}$ : The medians of the populations from which the groups were sampled are equal.

$H_{1}$ (two-sided): The medians of the populations from which the groups were sampled are not equal.

If $H_{0}$ is rejected ( $p$ value $<\alpha$ ), it can be determined that there was a significant difference in median values among other groups. To determine which groups are different from others, multiple comparison test performs for the paired comparison.

\section{Results}

A single-screw extrusion method for manufacturing boron rods to be used in remedial treatments of wood was used for the first time in the present study. Compared to conventional methods for producing boron rods, this new method needs no high temperatures and high-tech oven systems. The easiness of the method is one of the benefits
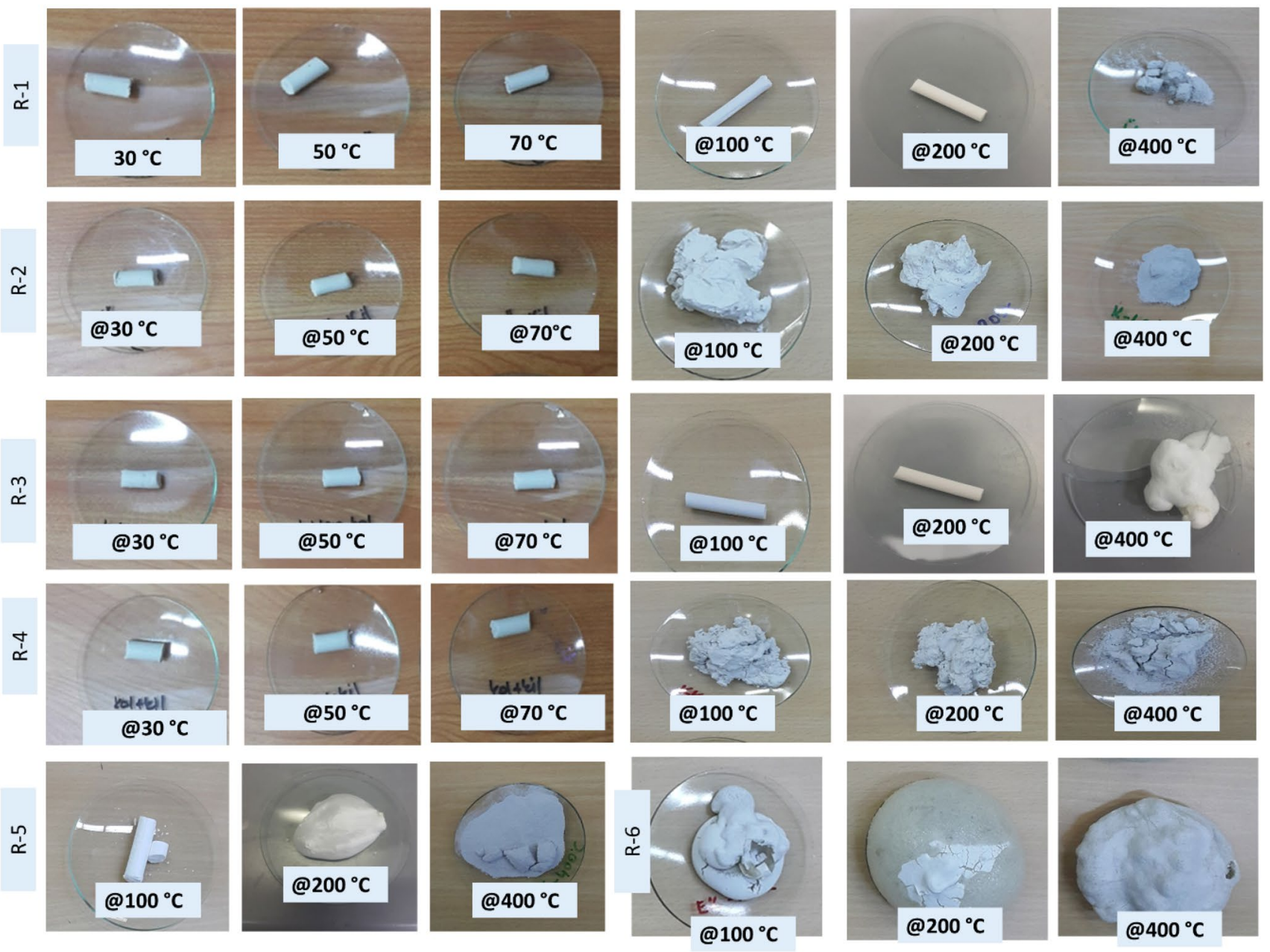

Fig. 1 Images of boron-based rods after thermal resistant test at low and high temperature 
Fig. 2 TG/DTG curves of raw ulexite mineral (a), raw colemanite mineral (b) and DOT (c)

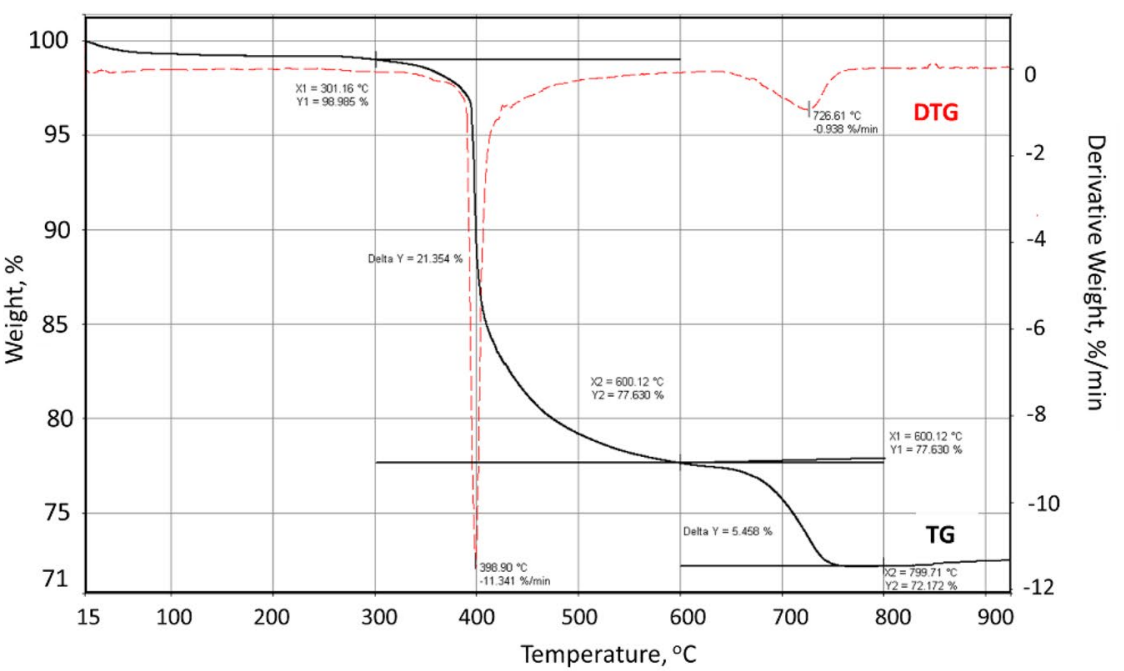

(a)

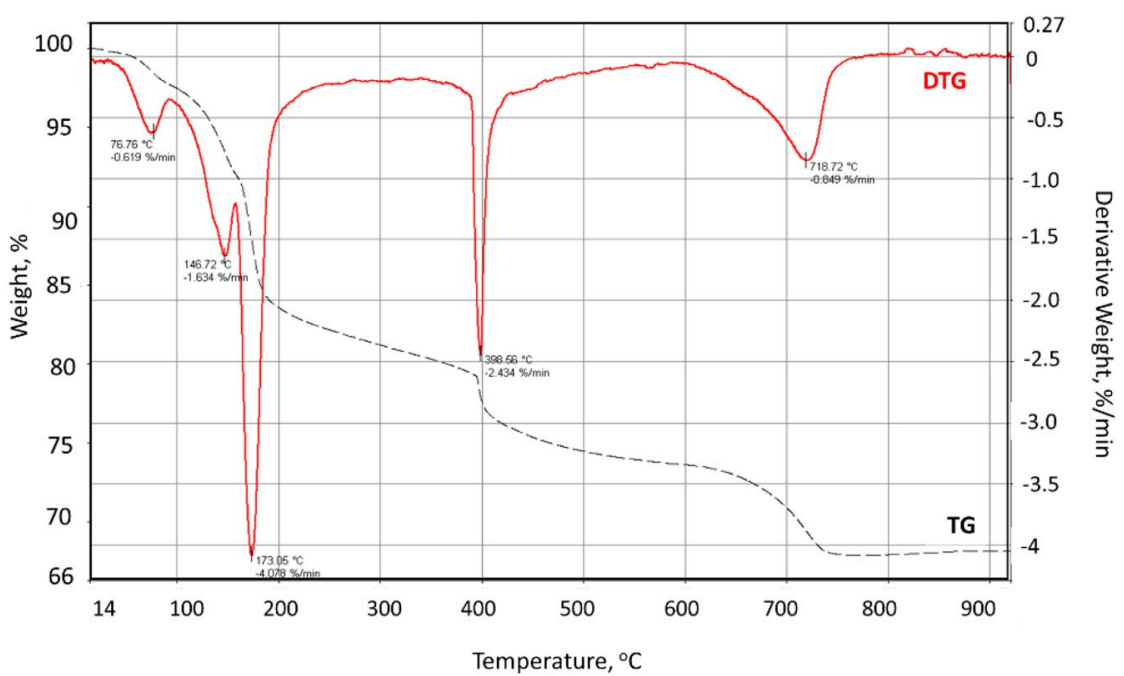

(b)

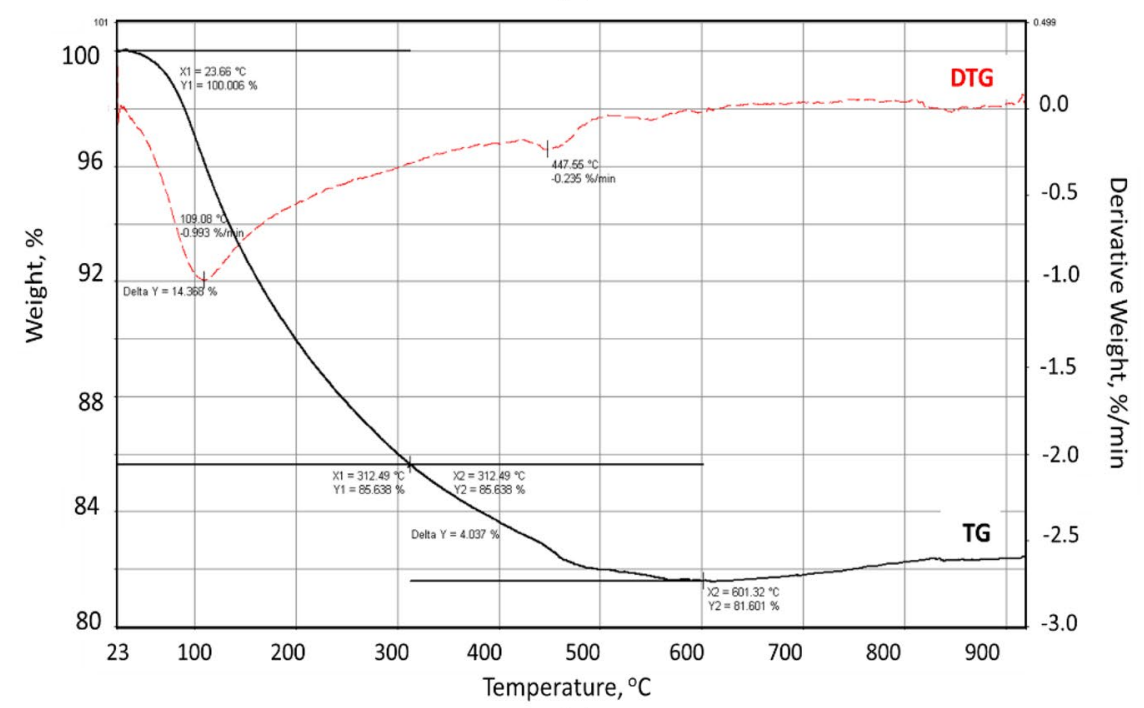

(c) 
Table 3 Determination of the impact of different boron rods on Vickers hardness value by Kruskal-Wallis test

\begin{tabular}{llll}
\hline & Test statistics & $\begin{array}{l}\text { Degree of free- } \\
\text { dom }\end{array}$ & Sig. ( $p$ value) \\
\hline $\begin{array}{l}\text { Kruskal-Wallis } \\
\text { test }\end{array}$ & 15.363 & 5 & 0.009 \\
\hline
\end{tabular}

$H_{0}: \operatorname{Med}_{R-1}=\operatorname{Med}_{R-2}=\operatorname{Med}_{R-3}=\operatorname{Med}_{R-4}=\operatorname{Med}_{R-5}=\operatorname{Med}_{R-6}$

$H_{1}$ : At least one group's median value is different from the others

as well. Boron-based rods were successfully manufactured from the prepared pastes in the given contents in Table 2 and images of boron-based rods are shown in Fig. 1.

The thermal behavior of boron minerals and DOT against heating was investigated by thermal analysis method. The TG/DTG curves of raw ulexite mineral, raw colemanite mineral, and DOT are given in Fig. 2 . When the TG/DTG curves of colemanite mineral were examined, no mass change has occurred at temperatures up to $300^{\circ} \mathrm{C}$. It was observed that heating from 300 to $800^{\circ} \mathrm{C}$ led to mass losses in two sequences steps. In the first step, there was a mass loss of $21 \%$ between 301 and $600{ }^{\circ} \mathrm{C}$, and in the second step, the mass loss was calculated as $6 \%$ along with the removal of all the water from the structure. For ulexite mineral, it was determined that the degradation began at $76^{\circ} \mathrm{C}$ and continued up to $240^{\circ} \mathrm{C}$. Mass losses of $8 \%$ and $17 \%$, with peak points at $146^{\circ} \mathrm{C}$ and $173^{\circ} \mathrm{C}$ were determined according to the DTG curve. With continued heating, the removal of the remaining $\mathrm{OH}^{-}$groups with the peaks of $398^{\circ} \mathrm{C}$ and $718^{\circ} \mathrm{C}$ occurred. It was found that $4 \mathrm{~mol}$ of water from DOT were completely released at temperatures up to $600^{\circ} \mathrm{C}$. As shown in Fig. 2, 14.36\% of mass loss occurred in the first step and after $400^{\circ} \mathrm{C}, 4 \%$ of mass loss was seen. Maximum peaks associated with these mass losses were determined as $109^{\circ} \mathrm{C}$ and $447^{\circ} \mathrm{C}$, respectively, from the DTG curve.

After the thermal analysis, the thermal resistant test was applied to determine the temperature range where the boron rods can maintain their structure. All of the heattreated boron rods at low temperatures $\left(30,50,70^{\circ} \mathrm{C}\right)$ did not show any macro-structural changes such as swelling and breakage in their structure. Macro-structural defects

Table 4 Pairwise comparison of boron rods in terms of Vickers hardness value

\begin{tabular}{lcl}
\hline Boron rods & Test statistics & Sig. ( $p$ value) \\
\hline R-4 versus R-2 & 0.333 & 0.939 \\
R-4 versus R-6 & -5.333 & 0.221 \\
R-4 versus R-5 & -7.000 & $0.098^{* *}$ \\
R-4 versus R-1 & 11.667 & $0.007^{*}$ \\
R-4 versus R-3 & 12.667 & $0.004^{*}$ \\
R-2 versus R-6 & -5.000 & 0.251 \\
R-2 versus R-5 & -6.667 & 0.126 \\
R-2 versus R-1 & 11.333 & $0.009^{*}$ \\
R-2 versus R-3 & -12.333 & $0.005^{*}$ \\
R-6 versus R-5 & 1.667 & 0.702 \\
R-6 versus R-1 & 6.333 & 0.146 \\
R-5 versus R-3 & 7.333 & $0.092^{* *}$ \\
R-5 versus R-1 & 4.667 & 0.284 \\
R-5 versus R-3 & 5.667 & 0.194 \\
R-1 versus R-3 & -1.000 & 0.819 \\
\hline
\end{tabular}

${ }^{*} p<0.05 ;{ }^{* *} p<0.10$
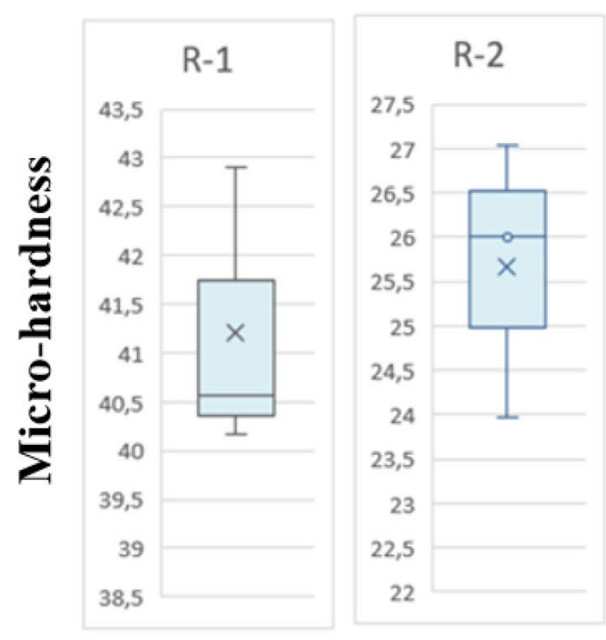
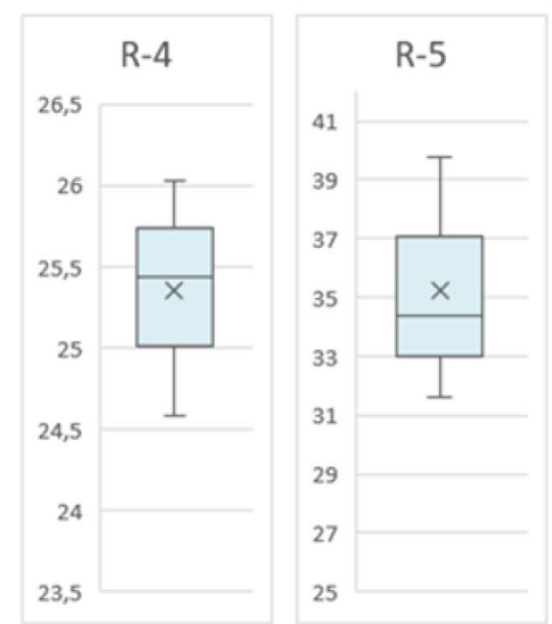

\section{Boron rods}

Fig. 3 Box-Whisker plot of micro-hardness of boron rods 
Table 5 Determination of the impact of different temperature levels on Vickers hardness value for each boron rods by Kruskal-Wallis test

\begin{tabular}{|c|c|c|c|}
\hline Boron rods and temperature levels & Test statistics & Degree of freedom & Sig. ( $p$ value) \\
\hline $\mathrm{R}-1$ versus $20^{\circ} \mathrm{C}, 30^{\circ} \mathrm{C}$, and $50^{\circ} \mathrm{C}$ & 0.267 & 2 & 0.875 \\
\hline $\mathrm{R}-3$ versus $20^{\circ} \mathrm{C}, 30^{\circ} \mathrm{C}$, and $50^{\circ} \mathrm{C}$ & 1.689 & 2 & 0.430 \\
\hline $\mathrm{R}-5$ versus $20^{\circ} \mathrm{C}, 30^{\circ} \mathrm{C}$, and $50^{\circ} \mathrm{C}$ & 5.956 & 2 & $0.051^{* *}$ \\
\hline
\end{tabular}

${ }^{*} p<0.05 ;{ }^{* *} p<0.10$ after high-temperature treatment were observed as can be seen in Fig. 1. The structure of rods containing ulexite and colemanite did not show any change at $100^{\circ} \mathrm{C}$ and $200^{\circ} \mathrm{C}$. However, the rod containing colemanite at $400^{\circ} \mathrm{C}$ became powder and lost its rod shape. In addition to this, a small amount of powder was observed in the ulexite-containing rod. While there was no change at $100^{\circ} \mathrm{C}$ in rods containing additives with R-5 and R- 6 , deterioration in rod volume due to swelling at $200{ }^{\circ} \mathrm{C}$ and $400{ }^{\circ} \mathrm{C}$ was observed. When the rods were heat-treated at varying temperatures $\left(100-400^{\circ} \mathrm{C}\right)$, no deterioration was observed in colemanite and ulexite rod forms up to $200^{\circ} \mathrm{C}$. However, when the temperature was reached up to $400^{\circ} \mathrm{C}$, the rods lost their form and were turned into powder (Fig. 1).

The Vickers hardness tests were run to understand the mechanical properties of the manufactured rods. There were two steps of the statistical approach of the study, which were performing the Kruskal-Wallis test and pairwise multiple comparisons in case of rejecting the null hypothesis of the test. In Table 3, the test statistics and the $p$ value of the Kruskal-Wallis test were 15.363 and 0.009 , respectively. Since the $p$ value was lower than 0.05 , it was revealed that the median values of boron rods were not equal (Fig. 3). Thus, pairwise multiple comparison tests were performed for each boron rod.

As a result of multiple comparison tests, the median values of Vickers hardness for R- $1, \mathrm{R}-3$, and $\mathrm{R}-5$ were relatively higher than R-2 and R-4 (Table 4). Although the median values of $R-1$ versus $R-3$ and $R-3$ versus $R-5$ were not significantly different from each other, it was decided to analyze the results of these rods at each temperature level, since the median values were higher than the others. The hardness values of ulexite- and colemanite-based rods were found similar to each other $(41 \pm 1.5 \mathrm{HV}$ and $41 \pm 1.0$ $\mathrm{HV}$, respectively). Also, micro-hardness measurements revealed that the hardness values of all the plasticizeradded boron rods decreased when compared with the rods without the plasticizer. Therefore, R-1, R-3, and R-5 were taken into consideration for further analysis.

Table 5 shows the Kruskal-Wallis test for selected boron rods at different temperature levels. The Vickers hardness distributions for each boron rod by temperature levels are shown in Fig. 4. The temperature had no significant impact on the median value of R-1 and R-3. On the other hand, the impact of temperature on R-5 was statistically significant. Once the pairwise comparison was performed to identify at which temperature level had a significant impact on R-5, it was revealed that the median value of R-5 at $50{ }^{\circ} \mathrm{C}$ degree was significantly lower than the others in Table 6. To compare the median values of R-1, R-3, and R-5 at $20^{\circ} \mathrm{C}, 30^{\circ} \mathrm{C}$, and $50^{\circ} \mathrm{C}$, separately, the Kruskal-Wallis test was performed. Table 7 shows the temperature levels had no significant effect on the median values of boron rods at $20^{\circ} \mathrm{C}$ or $30^{\circ} \mathrm{C}$. However, its effect became statistically significant at $50^{\circ} \mathrm{C}$. When pairwise comparison analysis was performed at $50^{\circ} \mathrm{C}$, it was seen that the median value of R-5 was significantly lower than others (Table 8). No significant change was observed in micro-hardness values of thermal treated boron-based rods manufactured from pure ulexite, colemanite, and DOT. However, when the temperature increased up to $50^{\circ} \mathrm{C}$ for DOT rods, there was a decrease in hardness due to the changes in its structure.

The density values of the rods were measured based on Archimedes' principle as 1.25, 1.65, 1.73, 1.84, 1.83, and $1.45 \mathrm{~g} / \mathrm{cm}^{3}$ for R1-R6, respectively. The rods with colemanite mineral had the highest density followed by DOT and ulexite rods. It was clear that the plasticizer added to the rod composition led to increases in density values of the rods. The plasticizer addition had the highest effect on ulexite rods in terms of increased densities.

Results of the solubility tests applied to the boron rods and boron compounds are given in Fig. 5 . Water solubility was examined using the amount of boron release as a function time. The amount of boron release during the solubility test from boron rods and boron compounds powder for $6 \mathrm{~h}, 1$ day, 2 days, and 4 days was determined by ICP-OES analysis. In this study, the impact of function time and form of the material on solubility is examined in Table 9. Besides, the Box-Whisker plot of boron release in solubility tests by boron rods and compounds are given in Fig. 5. According to Table 10, function time had an important factor on solubility in both rod and powder compounds. Once pairwise multiple comparison tests were performed, it was revealed that the solubility values of R-1 in rod form at 6 h, 1 day, and 2 days were not differentiated while the solubility value of R-1 at 4 days was significantly higher than the others. The solubility values of R-3 in rod form at $6 \mathrm{~h}$ and 1 day were not significantly 
Fig. 4 Box-Whisker plot of micro-hardness of boron rods for each temperature level
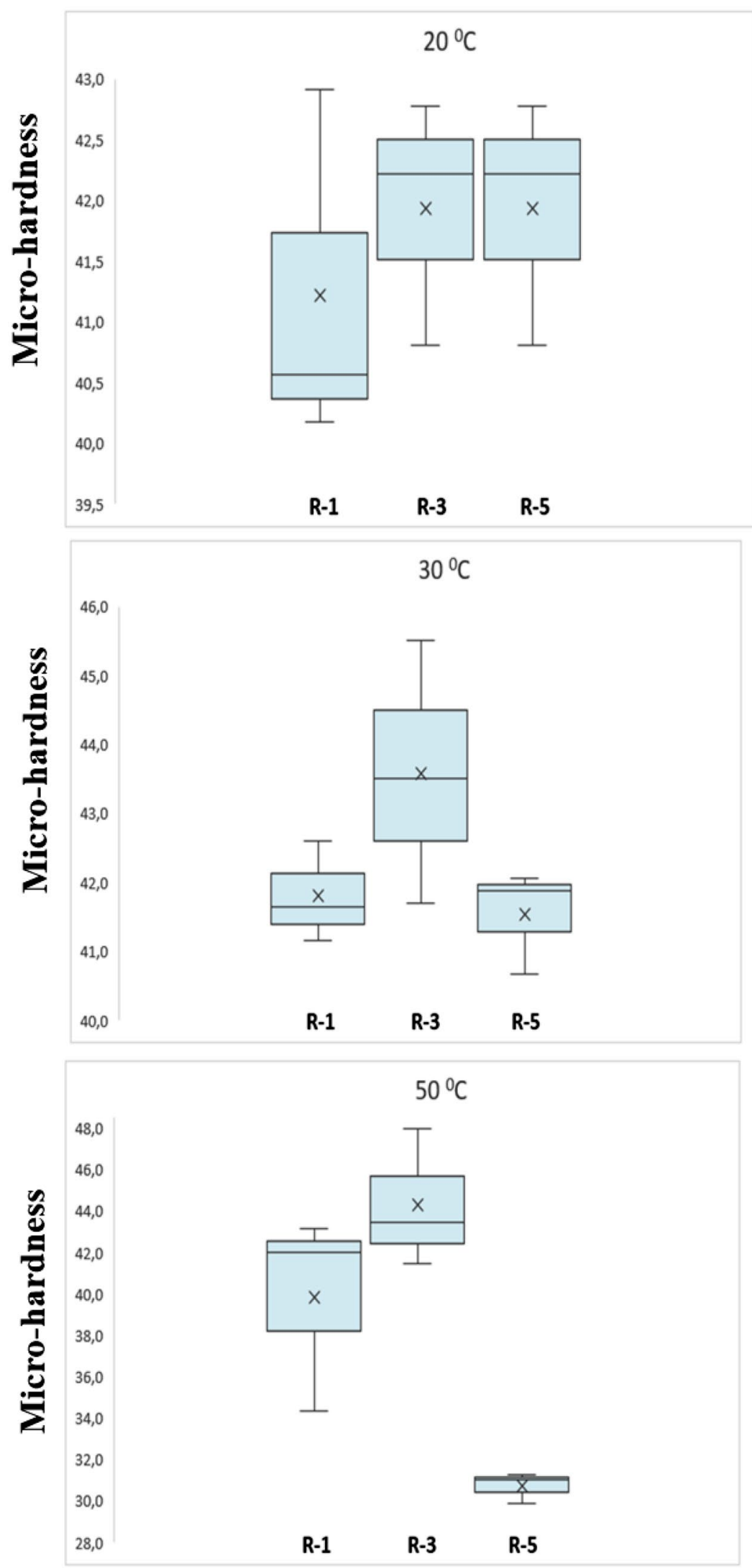
Table 6 Pairwise comparison of R-5 at different temperature levels

\begin{tabular}{lll}
\hline Temperature levels & Test statistics & Sig. ( $p$ value) \\
\hline $50^{\circ} \mathrm{C}$ versus $30^{\circ} \mathrm{C}$ & 3.967 & $0.098^{* *}$ \\
$50^{\circ} \mathrm{C}$ versus $20^{\circ} \mathrm{C}$ & 5.333 & $0.017^{*}$ \\
$30^{\circ} \mathrm{C}$ versus $20^{\circ} \mathrm{C}$ & 1.667 & 0.456 \\
\hline
\end{tabular}

${ }^{*} p<0.05 ;{ }^{* *} p<0.10$

Table 7 Determination of the effect of boron rods on Vickers hardness value at different temperature levels by Kruskal-Wallis test

\begin{tabular}{llll}
\hline $\begin{array}{l}\text { Boron rods at different } \\
\text { levels }\end{array}$ & Test statistics & $\begin{array}{l}\text { Degree } \\
\text { of free- } \\
\text { dom }\end{array}$ & Sig. ( $p$ value) \\
\hline $\mathrm{R}-1, \mathrm{R}-3$, and $\mathrm{R}-5$ at $20^{\circ} \mathrm{C}$ & 0.615 & 2 & 0.735 \\
$\mathrm{R}-1, \mathrm{R}-3$, and $\mathrm{R}-5$ at $30^{\circ} \mathrm{C}$ & 2.400 & 2 & 0.301 \\
$\mathrm{R}-1, \mathrm{R}-3$, and $\mathrm{R}-5$ at $50^{\circ} \mathrm{C}$ & 5.956 & 2 & $0.051^{* *}$ \\
\hline
\end{tabular}

${ }^{*} p<0.05 ;{ }^{* *} p<0.10$

Table 8 Pairwise comparison of boron rods at $50^{\circ} \mathrm{C}$

\begin{tabular}{lcl}
\hline Boron rods & Test statistics & Sig. ( $p$ value) \\
\hline R-5 versus R-1 & 3.967 & $0.098^{* *}$ \\
R-5 versus R-3 & 5.333 & $0.051^{* *}$ \\
R-1 versus R-3 & -1.667 & 1.000 \\
\hline
\end{tabular}

${ }^{*} p<0.05 ;{ }^{* *} p<0.10$

different from each other, but the solubility values of R-3 in rod form in 2 days and 4 days were significantly higher than others. On contrary to R-1 in rod, the solubility values of R-5 in rod form at $6 \mathrm{~h}, 1$ day, and 2 days were not differentiated from each other while the solubility value of R-5 at 4 days was significantly lower than the others. The solubility values of R-1 in powder form at $6 h, 1$ day, and 2 days were not differentiated from each other, but the solubility value of $\mathrm{R}-1$ in powder form in 4 days was significantly higher than others. Similar to the results in R-3 in rod form, the solubility values of R-3 and R-5 in powder form at $6 \mathrm{~h}$ and 1 day were not significantly different from each other, but the solubility values of R-3 and R-5 in powder form in 2 days and 4 days were significantly higher than others. In this study, the solubility values of the compounds by boron mineral and function time were compared using the Kruskal-Wallis. According to Table 10, the solubility values of R-1 in powder form were significantly higher than the rod form in 1 day, 2 days, and 4 days. In R-3, the solubility values were not significantly differentiated in $6 \mathrm{~h}$ or 1 day. In 2 days and 4 days, the solubility values of powder form were significantly higher than others. Besides, the solubility values of R-1 in powder form were significantly higher than the rod form in each function time level. Boron release from DOT in both powder and rod form is higher than ulexite and colemanite as expected due to higher water solubility of DOT than ulexite and colemanite. More importantly, when compared to the rod and powder form of boron compounds, it was found that the single-screw extrusion method did not result in any changes in watersolubility properties. For on-site applications, a singlescrew extrusion method can be applied to fabricate the boron rods without decreasing their solubility values which are related to the protection level.

Boron minerals can be classified based on their solubility due to the cations in the lattice structure. Colemanite and ulexite minerals are semi-soluble whilst borax and kernite minerals are soluble. As a result of their solubility properties, they behave differently in remedial treatments of wood. More importantly for on-site applications, boron rods show the same water-solubility properties compared with powder form of boron compounds. At lower temperatures, boron minerals release their crystal water, however further heating causes recrystallization and melting. Our results showed that boron-based rods tended to lose their forms at $400{ }^{\circ} \mathrm{C}$ and turned into powder form due to losses in its crystalline water. Moreover, solubility values of anhydrous boron minerals decreased. It is suggested that raw boron minerals can be employed in rod manufacturing for remedial treatments.

\section{Discussion}

Since raw boron minerals such as ulexite, colemanite have different water solubility, using such minerals at different degrees of water solubility in manufacturing boron-based rods for remedial treatments might result in a varying distribution of boron and long-term protection [15-18]. In our previous study by using boron rods from ulexite and colemanite rods, boron element content released in wood specimens from ulexite- and colemanite-based rods was considerably less than in wood specimens with DOT rods due to low solubility of the minerals Ulexite rods; however, resulted in elevated boron diffusion compared to colemanite rods due to better solubility [19]. On the other hand, the comparison of the properties of colemanite and ulexite to those of DOT could be useful. The use of raw, unpurified boron minerals could help minimize the cost of boron-based protection systems since ulexite and colemanite minerals are largely available in Turkey. The flow of pastes through a narrow die occurs by plastic deformation during extrusion [20] and the composition of paste in our study is adequate to yield the plasticity. The pastes were prepared with the appropriate hardness and the flow of paste in the extruder was very easy resulted in rod formation. Therefore, an additive is not required to add the 
6 hours

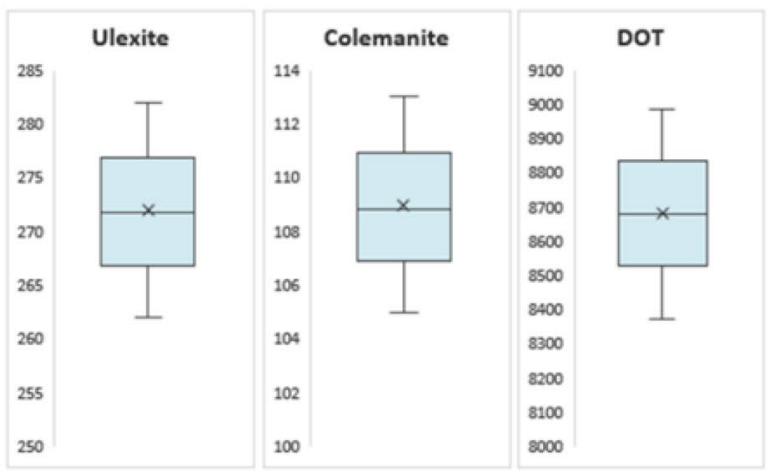

2 days

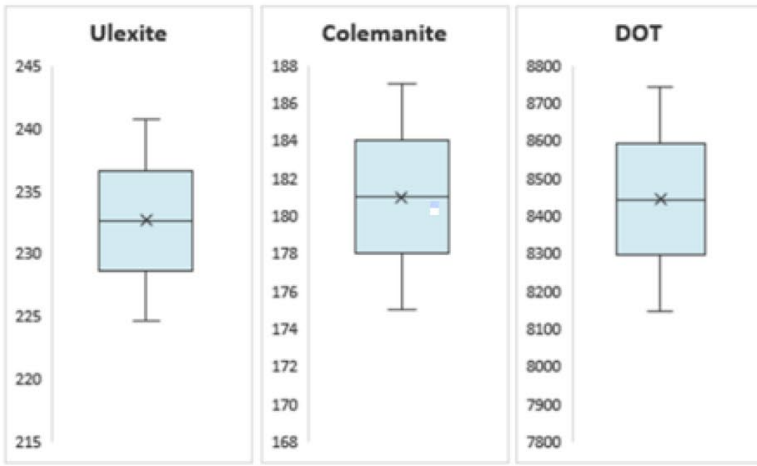

1 day

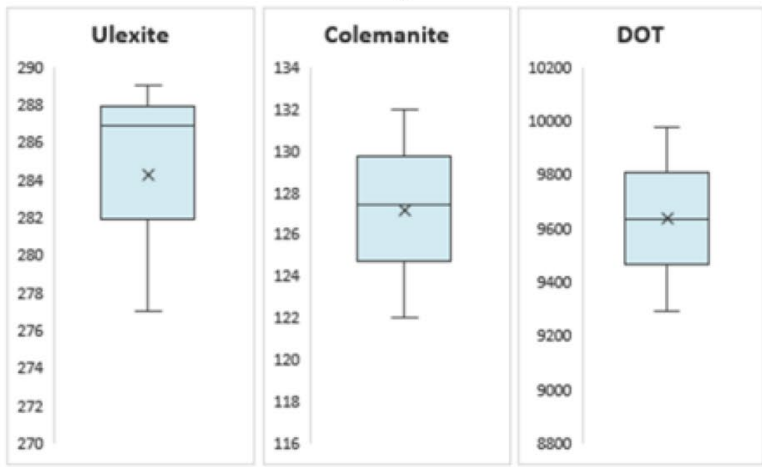

\section{4 days}

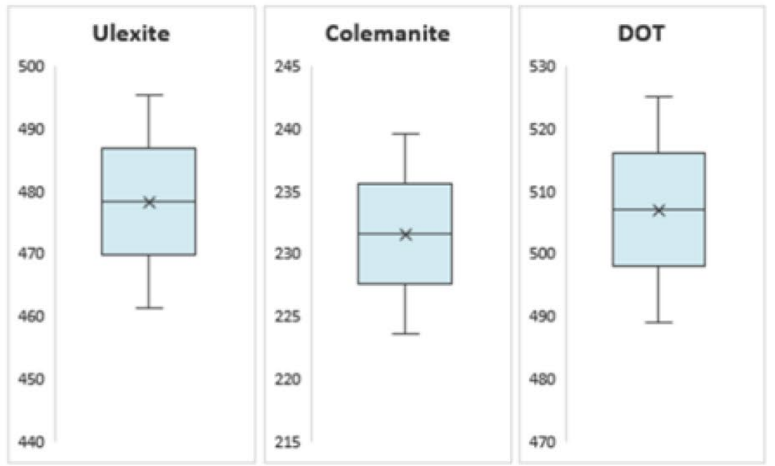

(a)

6 hours

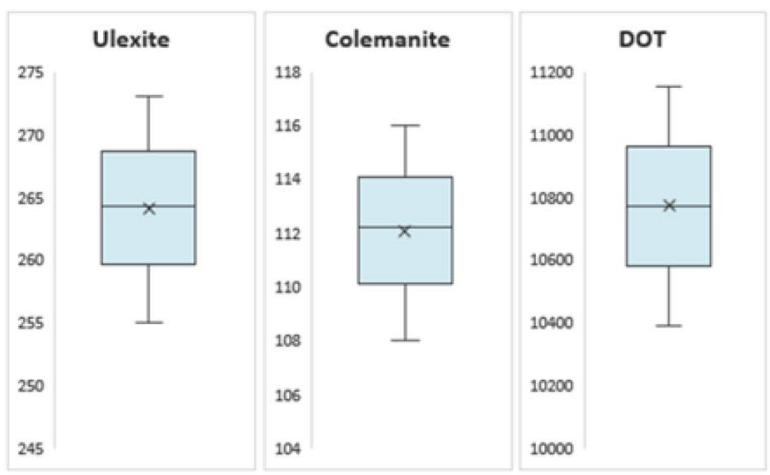

2 days

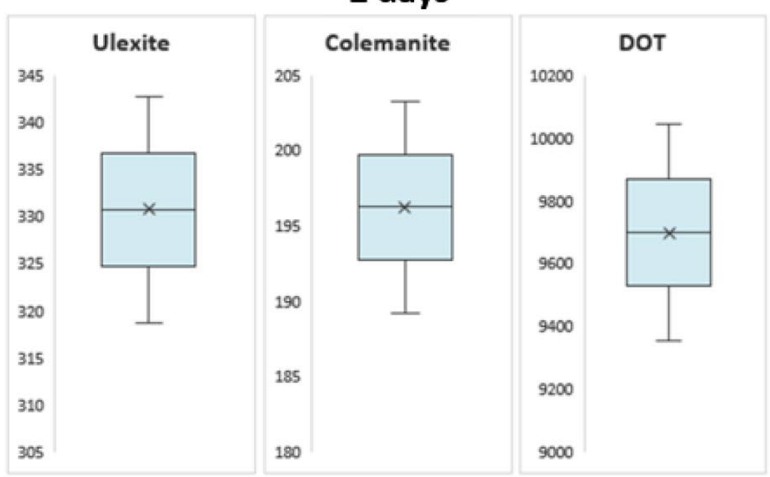

1 day

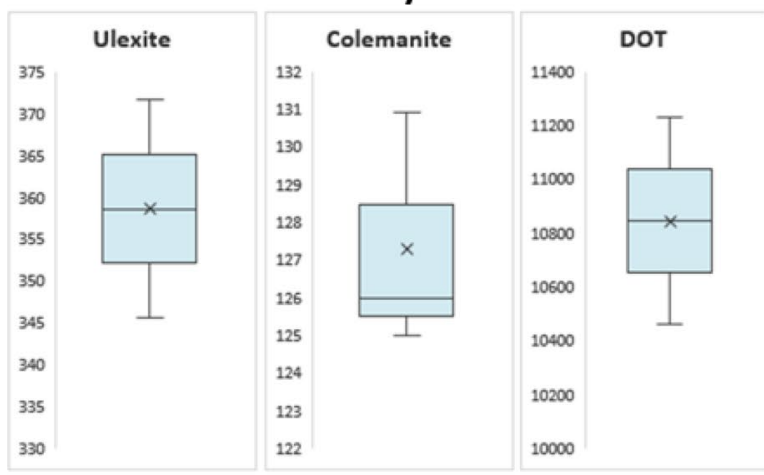

4 days

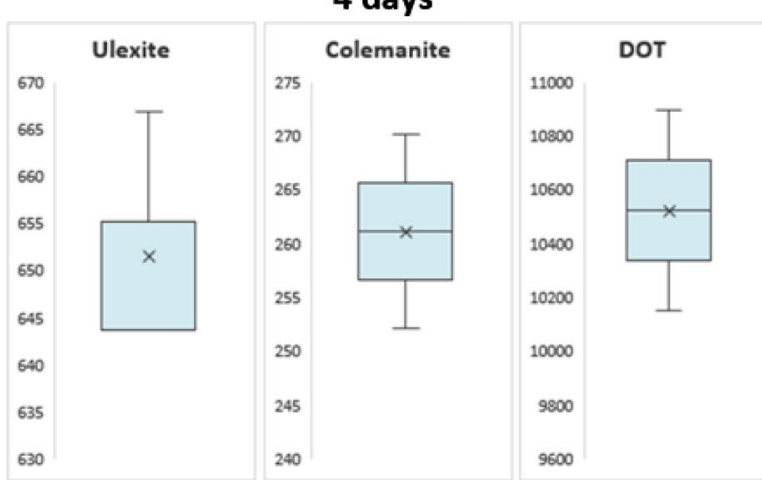

(b) 
4 Fig. 5 Box-Whisker plot of boron release in solubility tests, a boron rods, $\mathbf{b}$ boron compounds

past formulation according to the physical test results. Our results suggest that boron-mineral-based rods produced by the extrusion method could be used as commercial boron rods for remedial treatments of wood and woodbased constructions due to easiness of the production methods and unnecessariness of additional compounds.

\section{Conclusion}

The study is a part of a relatively larger research project focused on the development of new wood preservative systems based on boron minerals such as ulexite, colemanite, etc. In this part of the study, solid rods were successfully manufactured from ulexite and colemanite minerals. This is the first attempt to manufacture boron rods from ulexite and colemanite minerals by extrusion method. The proposed method for manufacturing solid boron rods for remedial treatments of wooden materials against biodegradation by fungi, insects, and termites may have potential over the commercially available procedures due to easiness in preparation of paste mixtures from raw boron minerals without further purification and low costs of extrusion method compared to common fusion methods.
Table 9 Determination of the impact of function time $(6 \mathrm{~h}$, 1 day, 2 days, and 4 days) on solubility at different boron compounds (rod and powder) by Kruskal-Wallis test
Table 10 Determination of the effect of compounds (rod and powder) on solubility at different function time for each boron mineral by KruskalWallis test

\begin{tabular}{llcll}
\hline Compounds & Boron minerals & Test statistics & $\begin{array}{l}\text { Degree of } \\
\text { freedom }\end{array}$ & Sig. ( $p$ value) \\
\hline Rod & R-1 (by function time) & 9.974 & 3 & $0.019^{*}$ \\
& R-3 (by function time) & 10.385 & 3 & $0.016^{*}$ \\
& R-5 (by function time) & 9.462 & 3 & $0.024^{*}$ \\
Powder & R-1 (by function time) & 10.421 & 3 & $0.015^{*}$ \\
& R-3 (by function time) & 10.384 & 3 & $0.016^{*}$ \\
& R-5 (by function time) & 6.692 & 3 & $0.082^{* *}$ \\
\hline
\end{tabular}

${ }^{*} p<0.05 ;{ }^{* *} p<0.10$

\begin{tabular}{lllll}
\hline Boron minerals & Function time & Compounds & Test statistics & Sig. $(p$ value) \\
\hline R-1 & $6 \mathrm{~h}$ & Rod (271.9) versus powder (264.1) & -0.655 & 0.513 \\
R-1 & 1 day & Rod (284.3) versus powder (358.6) & 1.964 & $0.050^{* *}$ \\
R-1 & 2 days & Rod (232.6) versus powder (330.7) & 1.964 & $0.050^{* *}$ \\
R-1 & 4 days & Rod (478.2) versus powder (651.4) & 1.964 & $0.050^{* *}$ \\
R-3 & $6 \mathrm{~h}$ & Rod (108.9) versus powder (112.1) & 0.655 & 0.513 \\
R-3 & 1 day & Rod (127.1) versus powder (127.3) & -0.218 & 0.827 \\
R-3 & 2 days & Rod (181.0) versus powder (196.2) & 1.964 & $0.050^{* *}$ \\
R-3 & 4 days & Rod (231.6) versus powder (261.1) & 1.964 & $0.050^{* *}$ \\
R-5 & 6 h & Rod (8680) versus powder (10,772.5) & 1.964 & $0.050^{* *}$ \\
R-5 & 1 day & Rod (9634.7) versus powder (10,844) & 1.964 & $0.050^{* *}$ \\
R-5 & 2 days & Rod (8444.5) versus powder (9698.4) & 1.964 & $0.050^{* *}$ \\
R-5 & 4 days & Rod (507) versus powder (10,522.7) & 1.964 & $0.050^{* *}$ \\
\hline
\end{tabular}

${ }^{*} p<0.05 ;{ }^{* *} p<0.10$

(): mean value of solubility 
Acknowledgements The boron compounds used were supplied by Eti Maden, Ankara, Turkey. The boron rods were manufactured at Remsan Refractory Material Industries Inc., Istanbul, Turkey. The work was supported by TUBITAK (The Scientific and Technological Research Council of Turkey) under 1005-National New Ideas and Products R\&D Funding Program (Project No. 1160149) and by Research Fund of the Yildiz Technical University (Project No. FYL-2017-3107).

\section{Compliance with ethical standards}

Conflict of interest The authors declare that they have no conflict of interest.

\section{References}

1. American Wood Protection Association (2012) Standard for wet ashing procedures for preparing wood for chemical analysis. AWPA A7-12, Birmingham

2. Kartal SN, Terzi E (2017) Recent developments in remedial and non-pressure wood protection systems: boron-based compounds. In: SHATIS'17 international conference on structural health assessment of timber structures, Istanbul, pp 549-557

3. Lebow RWA (2012) Guide for use of wood preservatives in historic structures. General technical report, FPL-GTR-217, US Department of Agriculture, Forest Service, Forest Products Laboratory, Madison. https://doi.org/10.2737/FPL-GTR-217

4. Bhatia TK (2002) Use of borate-treated wood as part of an IPM approach for durable and sustainable construction. In: Jones SC, Zhai J, Robinson WMH (eds) Proceedings of the 4th international conference on urban pests. Pocahontas Press, Charleston, pp 269-279

5. Kartal SN, Yoshimura T (2016) Borates: a natural way to protect wood against termites. Jpn Termit Control Assoc 1:7-10

6. Humar M, Peek RD, Jermer J (2006) Regulations in the European Union with Emphasis on Germany, Sweden and Slovenia. In: Environmental impacts of treated wood. ISBN 9780849364952 Published June 1, 2006 by CRC Press, London

7. https://www.epa.gov/ingredients-used-pesticide-products/ overview-wood-preservative-chemicals. Accessed 25 Aug 2020

8. Freitag C, Morrell JJ, Love CS (2011) Long-term performance of fused borate rods for limiting internal decay in
Douglas-fir utility poles. Holzforschung 65:429-434. https:// doi.org/10.1515/hf.2010.098

9. Chin C-W, McEvoy CN (1994) US patent no. 5,612,046. Production of shaped bodies which have fungicidal and insecticidal properties

10. Legard CCBK, AI JD (1978) Australian patent no. 527,240. Method of preserving timber

11. Beauford W, Spragg NJ, Millar M (1985) US patent no. 4,661,157. Production of shaped bodies of boron compounds

12. https://www.etimaden.gov.tr. Accessed 8 Apr 2020

13. Hassan SF, Gupta M (2005) Development of high performance magnesium nano-composites using nano- $\mathrm{Al}_{2} \mathrm{O}_{3}$ as reinforcement. Mater Sci Eng A 392:163-168. https://doi.org/10.1016/j. msea.2004.09.047

14. Sprent P, Smeeton NC (2001) Applied nonparametric statistical methods. Chapman and Hall, London

15. Birsoy R, Özbaş Ü (2012) Activity diagrams of borates: implications on common deposits. Carbonates Evaporites 27:71-85. https://doi.org/10.1007/s13146-012-0085-6

16. Özdemir Z, Zorlu S, Akyıldız M, Eryılmaz FY (2014) Determination of indicator plants for boron in the kirka (Eskisehir/ Turkey) boron deposit area. Int J Geosci 05:77-84. https://doi. org/10.4236/ijg.2014.51009

17. US Geological Survey Minerals Yearbook (2013) Boron (Advance Release) (2015) US Department of the Interior. US Geological Survey. https://minerals.usgs.gov/minerals/pubs/commodity/ boron/myb1-2013-boron.pdf

18. Terzi E, Kartal SN, Gerardin P, Ibanez CM, Yoshimura T (2017) Biological performance of particleboard incorporated with boron minerals. J For Res 28:195-203. https://doi.org/10.1007/s1167 6-016-0288-0

19. Kartal SN, Terzi E, Figen AK, Cordan M, Aydin S, Pişkin S (2019) Comparative evaluation of boron distribution from ulexite, colemanite and DOT rods in Scots pine wood. J For Res 1:1. https:// doi.org/10.1007/s11676-019-01024-6

20. Ananthakumar S, Manohar P, Warrier KG (2004) Effect of boehmite and organic binders on extrusion of alumina. Ceram Int 30:837-842. https://doi.org/10.1016/j.ceramint.2003.09.019

Publisher's Note Springer Nature remains neutral with regard to jurisdictional claims in published maps and institutional affiliations. 